\section{Helen Elsie Austin}

\section{JOHN S. HATCHER}

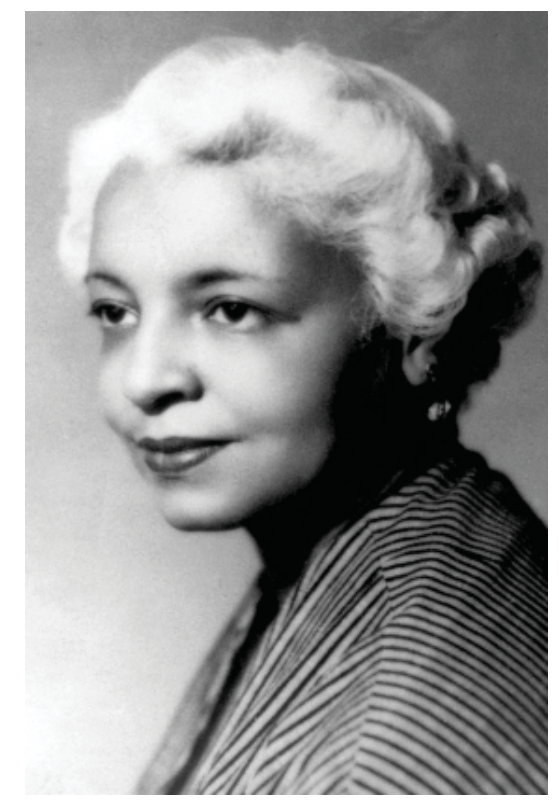

Helen Elsie Austin was born May 10, 1908, to Mary Louise Austin and George J. Austin, both of whom worked at the Tuskegee Institute and were friends with Booker T. and Margaret Washington at the same university. ${ }^{1}$ The family moved several times because George Austin (a veteran of the Spanish-American War) served as "Commander of Men" at schools in

1 Booker T. Washington was an American educator, writer, and noted speaker. In the latter part of the nineteenth century and the early part of the twentieth century, he was considered by many to be the most prominent African-American leader and spokesperson.

2 This was a position in the World War I period equivalent to contemporary commandants of university ROTC programs.
Alabama, in Texas, and-with America's involvement in World War I-at the Fort Des Moines, Iowa, Provisional Army Officer Training School.

By January 1920, the family had settled in Cincinnati, Ohio, where Mary Louise worked at a school named after Harriet Beecher Stowe. It is told that on her first day of high school, after the teacher had read from a textbook that the black race had contributed absolutely nothing to civilization but had been created to be subservient to the more fortunate races, Elsie stood up and said: "I was taught in a black school that Africans worked iron before Europeans knew anything about it. I was taught that they knew how to cast bronze in making statues and that they worked in gold and ivory so beautifully that the European nations came to their shores to buy their carvings and statues. That is what I was taught in a black school." This is how early the character of Elsie Austin manifested itself in what would prove to be a lifetime of daring, courage, and autonomy.

After graduating from high school in 1924, Austin and seven other African-American women students were admitted to the University of Cincinnati. Historically, there was limited attendance of black students at the university, and in the 1920s most of the African-American women were only allowed into the college of education. In addition, there were no black faculty; black students could not live in the dormitories, had limited access to the university pool, and were cautioned by the college administrator to be inconspicuous and to have low expectations. 
Not to be deterred, Austin and the other black female students decided they would go out for everything. They also made a solemn vow to finish that first year with honors in something. Their success in doing just so motivated the same college official to apologize to them.

Austin went on to be the first black woman to graduate from the University of Cincinnati Law School. She also passed the Indiana Bar as one of only twenty-two black women lawyers admitted by 1930 . In addition to this important achievement, while working on her law degree, Austin spent a year on the staff of the Rocky Mountain Law Review and later earned a placement at the Cincinnati Law Review. In 1931, Austin opened a law practice in Indianapolis, Indiana, and in 1933, she co-founded a law firm with Henry J. Richardson, Jr., in Ohio.

Over time, Austin had become increasingly incensed about the role of religion in dealing with racism. She approached her father to explain that she was leaning toward becoming an agnostic or even an atheist because all the religions not only practiced segregation but also seemed to be at war with one another.

While her father listened with understanding to her frustration, he told her that, before she abandoned religion entirely, she might do well to investigate the Bahá'í Faith. He knew about the Faith because he had attended monthly public meetings held by the long-established Cincinnati Bahá'í community and had made contact with some of its members.
Austin was interested, but she tempered her curiosity with caution. For two years or so, she carried Bahá'í literature with her, and she attended meetings, impressed particularly by prominent African-American lawyer Louis G. Gregory and by Dorothy Baker, whose wit, wisdom, and charismatic openness helped Austin conquer her cynicism about religion. She finally became a Bahá'í in 1934.

It was also in 1934 that Austin represented the National Association for the Advancement of Colored People at a hearing regarding the inequity of school allocations in Ohio. In addition, Austin was admitted to plead cases before the Ohio Supreme Court, and she was named to the Board of Trustees of Wilberforce University, a historically black college.

Over the next few years, she both led private classes on the Bahá'í Faith and served on an all-Cincinnati YWCA committee. But 1937 was a major turning point in Austin's life and career. She was appointed as an assistant attorney general for Ohio. She received an honorary Doctor of Laws degree from Wilberforce University because of this appointment. She also worked with the YMCA, and she was appointed to a regional committee tasked with overseeing the Bahá'í Faith in Ohio, Michigan, Indiana, and Kentucky. Finally, she was honored as an invited speaker at a symposium in Cleveland.

In 1946, Austin was elected to the National Spiritual Assembly of the United States, and later she went on pilgrimage to Haifa. In 1953, upon Shoghi Effendi's instigation of the Ten Year 
World Crusade- the major emphasis of which was to encourage Western Bahá'ís to pioneer to other countries to establish the "pillars" for election of the Universal House of Justice- the inspired Elsie Austin decided to pioneer to Morocco. At that time, Morocco was still a "virgin territory" as far as Bahá'í presence was concerned, so her relocation to that country earned her the title of "Knight of Bahá'u'lláh." While teaching at the American School of Tangier in Morocco, she helped establish Bahá'í communities in northern and western Africa. Austin was then elected to the National Spiritual Assembly of North West Africa, and, as a member of that institution, she was a delegate to the international convention electing the first Universal House of Justice in 1963.

In addition to pioneering internationally and serving on national bodies, Austin served on Local Spiritual Assemblies in five different countries: the United States, Morocco, Nigeria, Kenya, and the Bahamas. She also served as one of the first members of the Auxiliary Board-established in 1954 to assist Hands of the Cause of God-aiding Hand of the Cause Músá Banání. During this time, she also wrote Above All Barriers: The Story of Louis G. Gregory (1955).

In 1958, she was appointed executive director of the United States National Women's Council, and from 1960 to 1970, she was a Foreign Service officer, serving as a cultural attaché with the United States Information Agency in Lagos, Nigeria, and later in Nairobi, Kenya. Austin retired from the Foreign Service in 1970.

In 1975, Austin chaired the Bahá'í delegation to the International Women's Conference in Mexico City, and in 1982, she worked with the PhelpsStokes Fund in China, inspecting schools, businesses, and community services affecting education and opportunities for minorities. In 2000, the University of Cincinnati named a scholarship in her honor. She died of congestive heart failure on October 26, 2004, whereupon the Universal House of Justice mandated that pubic memorial services for her be held at the Houses of Worship in the United States and Uganda.

\section{Scholarship on Elsie Austin}

The Bahá'i World, volume 33 (20042005), honored Austin's passing with a lengthy "In Memoriam." Yet, so far as we can determine, no extensive biography has been published, nor has any major study of her contribution to the advancement of racial equality and her immense contribution to the spread of the Bahá'í Faith. One hopes that some capable writer will undertake a comprehensive study of her life and contributions.

An article by Austin, titled "Faith, Protest, and Progress," was published in volume 8 , number 2 , of The Journal of Bahá'i Studies and is available in electronic format on the Association for Bahá'í Studies website. 